\title{
Reactional modification of the primitive mantle by basaltic melts: an evidence from mantle-derived xenoliths of the Vitim Plateau (Russia)
}

\author{
Litasov Yu.D. ${ }^{1,2}$, Niida K. ${ }^{2}$, Litasov K.D. ${ }^{1}$
}

1. United Institute of Geology. Geophysics and Mineralogy SB RAS. Novosibirsk. 630090. Russia

2. Department of the Earth and Planetary Sciences. Hokkaido University. Sapporo 060 Japan

Mantle peridotite xenoliths in alkaline basalts of the Vitim Plateau were examined to determine a presence of hydrous minerals and other signs of interaction between hydrous melt/fluid and wall lherzolite. Finds of amphibole and phlogopite were recorded earlier (Ashchepkov, 1991; Dobretsov, Ashchepkov, 1991; Ionov et al., 1993). Here we present new data on occurrence of hydrous minerals and coexisting phases in mantle xenoliths, and discuss a probable composition of agent modifying wall peridotite

The xenoliths were carried up during different stages of volcanic activity. It allows to follow the lithospheric mantle dynamics (Litasov, Litasov, 1998). The Vitim geotherms of different ages were verified by a comparison with amp and phl experimental stability fields in the upper mantle. Reversed check allowed to specify a position of hydrated peridotites in the geotherms. The most attention was paid for the xenoliths from volcanic rocks of two different stages with a time break about $15 \mathrm{Ma}$. Picrobasalt from the Bereya quarry corresponds to Miocene. Basanites of younger volcanoes and lava flows correspond to Plio-Pleistocene. The majority of hydrated peridotite xenoliths was found in the Miocene picrobasalt. However, they are rare in Plio-Pleistocene rocks.

Two types of modification were determined by an appearance of added phases - vein type and interstitial type. The vein type is presented by (1) phlogopite-clinopyroxene veins, (2) phlogopite-pargasite and/or phlogopite-kaersutite veins, and (3) pargasite veins. The interstitial type includes (4) interstitial phlogopite and (5) interstitial pargasite.

(1) Phl-cpx veins is the most common vein type in the Vitim xenoliths. It is also the only type found in the Plio-Pleistocene volcanics. These veins cut garnet and spinel-garnet lherzolites from picrobasalt and spinel-garnet lherzolites from basanites. They are composed of graphic phl-cpx intergrowths testifying to their simultaneous crystallization. Rare syngenetic pargasite inclusions can be found in cpx. The vein width varies from $\mathrm{mm}$ to $\mathrm{cm}$ order (observed in the composite xenoliths), showing the steps of crack propagation during a melt/fluid movement. Contacts with wall lherzolite are sharp. Occasionally, reactional opx-rich zones are developed around wide veins (the width of zones comprises $20-30 \%$ of vein thickness)

(2) Phl-amp veins cut only xenoliths from the Miocene picrobasalt. The wall rocks are ga, spga and sp lherzolites. The veins with adcumulative texture are composed of large isometric pargasite/kaersutite and phl grains. The vein width is $\mathrm{mm}$ to $\mathrm{cm}$ order. These veins are always surrounded by reactional zones composed of opx, and rarely - cpx. Within zones, fine-grained clusters of cpx replaced by opx in presence of parg may be observed. The width of reactional zones is equal or exceeds the vein thickness. According to mineral chemistry and mode of occurrence, rare garnet harzburgites and orthopyroxenites with interstitial phl correspond to this type and represent reactional zones of large hypothetical veins/dykes. Among the Plio-Pleistocene xenoliths, there are rare «dry» harzburgites without visible hydrous minerals, which are interpreted, due to mineral chemistry and texture, as the fragments of reactional zones inherited from earlier stages.

(3) Amp veins in sp-ga lherzolites from picrobasalt are composed of large $10 \mathrm{~mm}$ parg grains. Cpx is replaced by opx along the contacts. In places, $1 \mathrm{~mm}$ parg rims around ga are developed.

(4) Interstitial phlogopite was found in ga, sp-ga and sp lherzolites from the Miocene picrobasalt. Commonly, phl occurs as rare tabular grains irregularly distributed in the host rock. Its 
secondary origin is confirmed by phl grains occasionally cutting primary lherzolitic minerals. The composition of primary minerals does not change.

(5) Interstitial pargasite was found only in sp lherzolites from the Miocene picrobasalt. It forms fine-grained aggregates surrounding $\mathrm{sp}$ in coarse-grained protogranular sp lherzolites. Rare phl inclusions were found in parg and coexisting opx.

Variation diagrams showed three directions of mineral composition change reflecting reactional relationship between modifying agent and wall peridotite (Fig. 1).
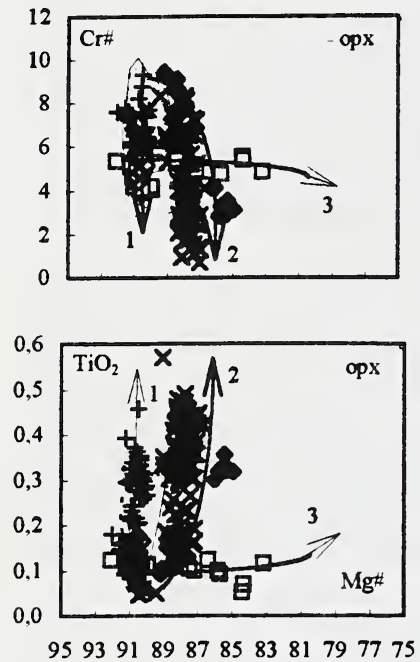
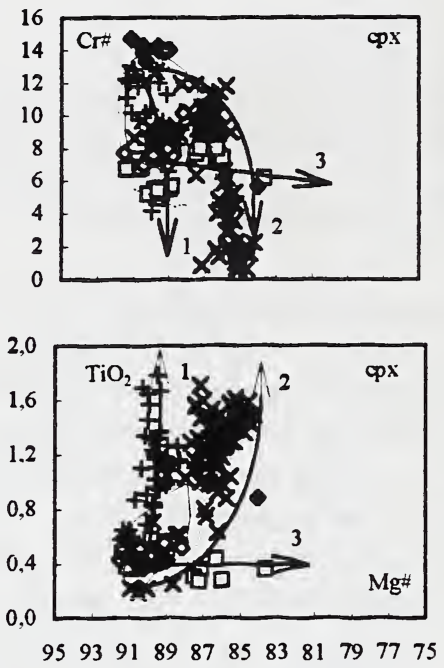

Fig. 1. Pyroxene compositions. Solid line primitive garnet peridotites. dashed line primitive spinel peridotites. Trends are shown for (1) lherzolites with phl-cpx veins. (2) with amp-phl veins. and (3) with interstitial pargasite.

I. Near the contacts with phlcpx veins, a decrease in $\mathrm{Cr} \#$ and increase in $\mathrm{TiO}_{2}$ with slight decrease in $\mathrm{Mg \#}$ were detected for pyroxenes and garnet of the wall lherzolite. The phl composition is uniform.

II. Abrupt decrease in $\mathrm{Cr} \#$ and increase in $\mathrm{TiO}_{2}$ were detected for pyroxenes and garnet near phl-amp

veins. $\mathrm{Mg \#}$ decreases in all peridotite minerals. In pargasite the increase in $\mathrm{Cr}, \mathrm{Mg \#}$ and decrease in $\mathrm{TiO}_{2}$ occur towards the wall rock.

III. In sp lherzolite with interstitial parg, abrupt decrease in Mg\# for all phases was fixed even within hand-sized samples. The amount of other major elements remains uniform.

Determined trends achieve only a tendency of compositional change, because an equilibrium between melt and wall is not reached. Nevertheless, we have tried, using end compositions for secondary and modified minerals, to estimate probable composition of modifying agent by mineral/melt distribution coefficients

The distribution coefficient olivine/melt is $K_{D}=0.30$ (Roeder, Emslie, 1970). Forsterite in olivine coexisting with the Vitim volcanics is $\mathrm{Fo}_{\mathrm{O}}=88.8 \%$ for picrobasalt, and $\mathrm{Fo}=73-82 \%$ for basanites. The first correlates with olivine $\mathrm{Mg \#}$ near amp-phl veins. Reactional trends are best expressed in opx and cpx compositions (Fig.1). There is an abrupt decrease in Cr\#, moderate decrease in $\mathrm{Mg \#}$, and increase in $\mathrm{TiO}_{2}$ towards amp-phl veins. Calculated $\mathrm{TiO}_{2}$ in coexisting melt should be 2-3 wt.\% ( $\mathrm{K}_{\mathrm{D}}$ from Hart, Dunn, 1993). The $\mathrm{Cr}$ value in melt coexisting with opx should be within 200-300 ppm. All the results are in a good agreement with observed values for the volcanic rocks. Here we exclude other estimations. They also support our main conclusion.

Thus, three agents modifying wall lherzolite may be described as following: (1) phl-amp veins were crystallized from $\mathrm{Cr}$-depleted (relative to peridotite) $\mathrm{Fe}$-, Ti-rich picritic melt resembling the Miocene picrobasalt; (2) differentiated Fe-rich melt (probably basanitic) percolates through magma chamber walls to form interstitial pargasite around spinel; (3) phl-cpx veins were formed by high magnesian, Cr-poor, Ti-rich melt. The last is not present among erupted volcanics. It could be crystallized in the depth at earlier stages of volcanic activity, or it is the result of long-term percolation through the peridotite host. Probably, signs of such melts percolating through peridotites are fixed in micro-cracks by autoradiography (Dobretsov et al., 1992). An agent forming interstitial phlogopite is not identified. It could be a fluid or volatile-rich melt separated from plume head in pre- 
magmatic stages and percolated through the lithospheric mantle. Temperature decreasing should make such liquid being saturated in volatiles and reacting with the host to form phlogopite.

An age difference of the host volcanics allows an estimation of changes in interaction between magma and wall peridotite from Miocene to Pleistocene. The phlogopite was found in xenoliths of both age volcanics, whereas the amphibole was described only in the Miocene xenoliths. A cause of difference in metasomatism was defined not only by the composition of magmas, but also by melt temperatures. Temperature difference between the host peridotite and melt was larger in Miocene, thus the hot picritic melt became saturated in water and other volatiles while temperature decrease. As the result, larger amount of hydrous phases was formed in Miocene, than in Pleistocene, when the basanitic melts rised.

We stratified modification types by the depth according to PT calculations for less modified parts of composite xenoliths. Finally, the following scheme of reactional modification for the Vitim upper mantle is suggested.

Before the rifting started, the upper mantle was composed of moderately heterogenous spinel and garnet lherzolites with composition fitting model primitive mantle composition. The facial transition occurred at $\mathrm{P}=23-19 \mathrm{kbar}$. All calculations are made using BM85 termometer and NG85 barometer (Bertrand, Mercier, 1985, Nickel, Green, 1985)). In Middle Miocene, the upper mantle was modified by melt replacement and metasomatism near numerous magma channels. It caused a formation of following modification types: interstitial phlogopite - $\mathrm{P}=31-20 \mathrm{kbar}$; phl-cpx veins $\mathrm{P}=28-24 \mathrm{kbar}$; phl-amp veins $-\mathrm{P}=26-22 \mathrm{kbar}$; pargasite veins $-\mathrm{P}=23-22 \mathrm{kbar}$; interstitial pargasite $\mathrm{P}<22 \mathrm{kbar}$. From Miocene to Pleistocene the upper mantle was heated $50^{\circ} \mathrm{C}$ in average (Ashchepkov et al., 1994). Phl-cpx veins formed at $\mathrm{P}=23-21 \mathrm{kbar}$, i.e. the pressure difference is $3-5 \mathrm{kbar}$ comparing with Miocene.

\section{References}

Ashchepkov. I.V.. 1991. Deep-seated xenoliths of the Baikal Rift.: Nauka publishing. Novosibirsk. $160 \mathrm{pp}$.

Ashchepkov I.V.. Litasov Yu.D.. and Dobretsov N.L.. 1994. Pyroxenites and composite garnet peridotite xenoliths from picrite-basalt. Vitim plateau (Trans Baikal): Implications for thermobarometry and mantle reconstruction: In Kimberlites. related rocks and mantle xenoliths, Spec. Issue 1/A. Proceed. $5^{\text {th }}$ IKC. Rio de Janeiro. Brasil. CPRM. p.455-466.

Bougault H., Joron J.L., and Treul M. 1980. The primordial chondritic nature and large-scale heterogeneities in the mantle: evidence from high and low partition coefficient elements in oceanic basalts: Phil. Trans. R. Soc. Lond., v.A297, p.203-213.

Bertrand P.., and Mercier J.-C.C., 1985. The mutual solubility of coexisting ortho- and clinopyroxene: toward an absolute geothermometer for the natural system?: Earth Planet. Sci. Lett., v.76. p.109-122.

Dobretsov N.L.. and Ashchepkov I.V.. 1991. Composition and evolution of the upper mantle in rift zones (on the example of the Baikal Rift Zone: Geology and Geophysics. v.1. p.5-14.

Dobretsov N.L.. Ashchepkov I.V.. Simonov V.A., and Zhmodik S.M., 1992. Interaction of the upper mantle rocks with deep-seated fluids and melts beneath the Baikal Rift Zone: Geology and Geophysics, v.5, p. 3-21.

Hart S.R., and Dunn T., 1993. Experimental cpx/melt partitioning of 24 trace elements: Contrib. Mineral. Petrol., v.113, p.1-8.

Ionov D.A., Ashchepkov I.V., Stosch H.-G.. Witt-Eickschen G., and Seck H.A., 1993, Garnet peridotite xenoliths from the Vitim volcanic field. Baikal Region: the nature of the garnet-spinel peridotite transition zone in the continental mantle: Journal of Petrology, v.34, p.1141-1175.

Litasov Yu.D., and Litasov K.D.. 1998, Mantle geotherms of different ages as an evidence for decreasing thickness of continental lithospheric mantle during rifting: Transact. (Doklady) Russian Akad. Sci.. in press.

Nickel K.G., and Green D.H.. 1985. Empirical geothermobarometry for garnet peridotites and implications for the nature of the lithosphere, kimberlites and diamonds: Earth Planet. Sci. Lett., v.73, p.158-170.

Roeder P.L., and Emslie R.F.. 1970. Olivine-liquid equilibrium: Contrib. Mineral. Petrol., v.29, p.275-289.

Tronnes R.G., Canil D., and Wei K., 1992, Element partitioning between silicate minerals and coexisting melts at pressures of 1-27 GPa, and implications for mantle evolution: Earth Planet. Sci. Lett., 1992, v.111, p.241255 . 